\title{
First record of Turkish Gecko Hemidactylus turcicus (Linnaeus, I758) populations for Piedmont, Italy (Sauria Gekkonidae)
}

\author{
Matteo Riccardo Di Nicola', Daniele Raimondi², Roberto Ghiglia ${ }^{3}$ \& Thomas Zabbia ${ }^{4 *}$ \\ ${ }^{1}$ Via Bobbio, 20144 Milano (MI) \\ ${ }^{2}$ Via Pietro Cossa, 10146 Torino (TO) \\ ${ }^{3}$ Via Santa Margherita, 12051 Alba (CN) \\ ${ }^{4}$ Via Giuseppe Ungaretti, 22030 Orsenigo (CO) \\ *Corresponding author, email: zthomas@hotmail.it
}

\begin{abstract}
This work reports the first occurrence of Hemidactylus turcicus (Linnaeus, 1758) (Sauria Gekkonidae) populations in Piedmont (Italy), one in the city of Turin and the other in Valle Talloria, Cuneo Province. They represent two new northern mainland sites for the species, which likely arrived in these areas by indirect anthropic transport.
\end{abstract}

KEY WORDS Hemidactylus turcicus; new record; Piedmont; population; Turkish Gecko.

Received 10.04.2020; accepted 26.05.2020; published online 30.06.2020

\section{INTRODUCTION}

The Turkish Gecko Hemidactylus turcicus (Linnaeus, 1758) is a polytypic species with a circummediterranean distribution and a complex systematic framework (Sacchi \& Delaugerre, 2011). In Italy, it is mainly distributed in coastal areas and on most of the islands, with more records for the Tyrrhenian side than for the Adriatic one (Venchi, 2006; Sacchi \& Delaugerre, 2011; Di Nicola et al., 2019). The species prefers rocky habitats, both natural and anthropic, and it is more active at dusk and at night (Speybroeck et al., 2016; Di Nicola et al., 2019). Hemidactylus turcicus is not considered as a threatened species and is listed as Least Concern (LC) both in the national and global IUCN Red Lists (Rondinini et al., 2013; IUCN, 2019).

Although the origins of the Italian $H$. turcicus populations are not sufficiently investigated, the populations of the inland areas of northern regions and north of the Conero on the Adriatic coast are likely to be present due to anthropic introduction and subsequent acclimatization (Venchi, 2006; Sacchi \& Delaugerre, 2011). Similarly to what has been hypothesised for the Moorish Gecko Tarentola mauritanica (Linnaeus, 1758), the introduction of the Turkish Gecko in the inland areas of Northern Italy could have occurred by accidental transport by trucks, trains or ships, by vehicles of tourists returning home from Mediterranean locations and, to a lesser extent, by voluntary releases (Nardelli et al., 2016; Novarini, 2017). Both species are synanthropic and well adapted to living in urban contexts (Bonardi \& Sindaco, 2004; Di Nicola et al., 2019).

Herein we report the first records of $H$. turcicus populations for the Piedmont region, which are added to the naturalised populations of this species that have already been observed in several areas of Northern Italy, in particular in the Po Valley (e.g. Bonardi \& Sindaco, 2004; Benà, 2007; Nardelli et al., 2016; Novarini, 2017; Pegorini \& Ghezzi, 2019). 


\section{MATERIAL AND METHODS}

In Summer 2019, one of the authors (D.R.) found several individuals of Turkish Gecko, both adults and juveniles, on the wall of an apartment building situated on Via Pietro Cossa, Turin (258 m a.s.1., coordinates: $45^{\circ} 05^{\prime} 45^{\prime \prime} \mathrm{N}, 7^{\circ} 38^{\prime} 17^{\prime} \mathrm{E}$ ) (Figs. 1, 2). More specifically, the geckos were spotted on three different days: a single adult individual observed on 17th July 2019; four new adult individuals and one juvenile observed on 2 nd August 2019; another juvenile observed on 3rd August 2019. On 2nd and 3rd August 2019, the presences of the already spotted adults were also reconfirmed. The different individuals were compared by photo identification.

The other observation concerns the finding of many individuals in the Province of Cuneo. Another author (R.G.) found more than 20 adult individuals, five of which with regenerated tails, on the walls of a private house and of an adjacent warehouse (outside and inside) situated on Provincial Road 130,
Valle Talloria, Cuneo, $210 \mathrm{~m}$ a.s.1., approximate coordinates: 44³91'N, 75917'E (Figs. 3, 4). The geckos were spotted on 7th June 2019 from about $9.00 \mathrm{pm}$ to $11.00 \mathrm{pm}$ (data reported even on iNaturalist), after that the owner of the property reported seeing them certainly for more than a year. Based on his personal experience, no other observations are known for Valle Talloria up to date.

\section{DISCUSSIONS AND CONCLUSIONS}

Excluding the populations described here, $H$. turcicus has been reported for Piedmont solely on the basis of two single individuals through the Ornitho web portal (specifically, an individual in October 2018 in Turin and one in October 2019 in Settimo Torinese).

Since the Turkish Gecko is a thermophilic species, its acclimatization in a new area could depend on the trend of the mean annual temperatures, specifically of the minimum ones (Pegorini \&
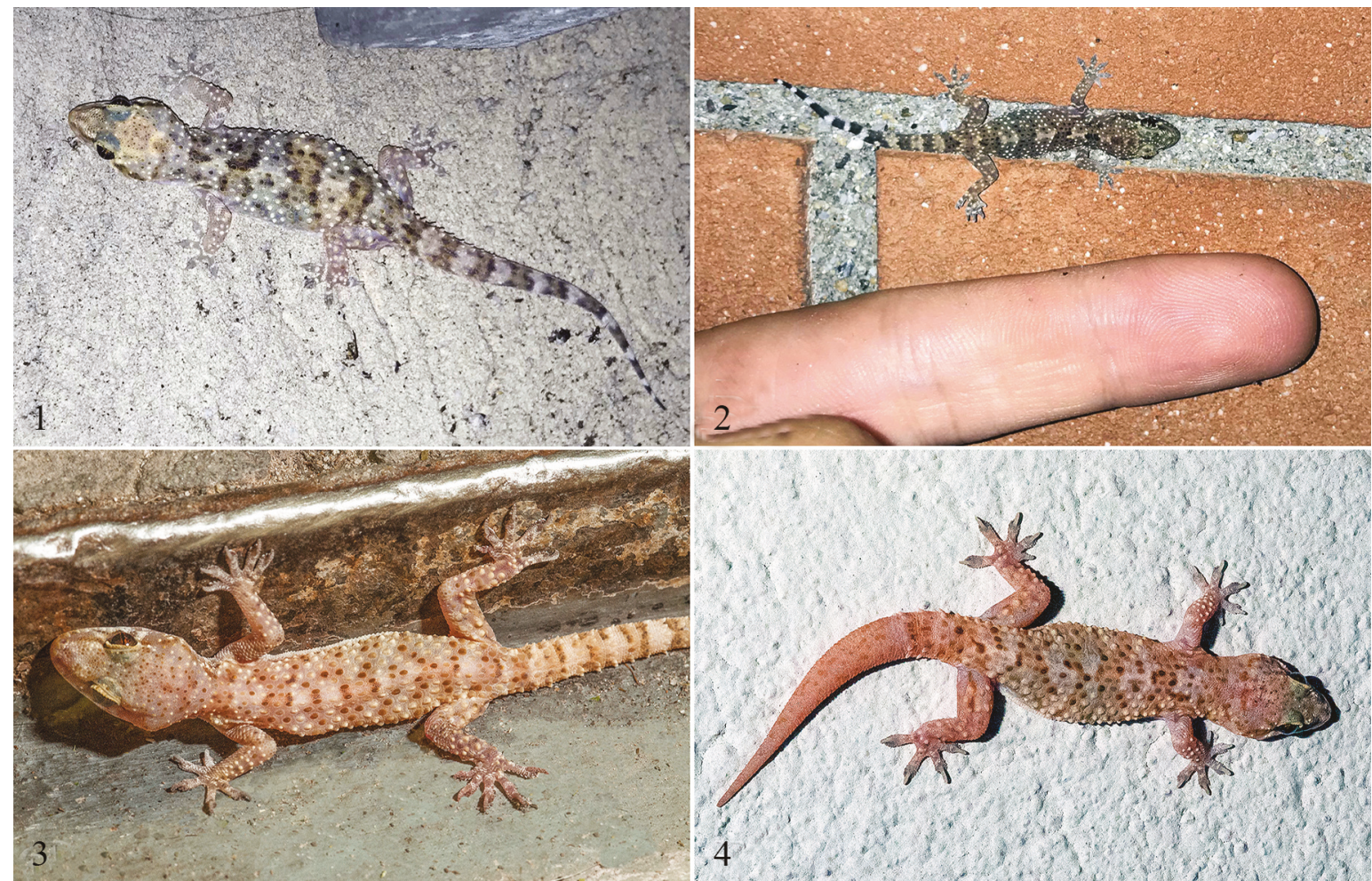

Figures 1-4. Hemidactylus turcicus from the Piedmont populations (Italy): adult with intact tail (Fig. 1) and young (Fig. 2) from Turin; adult with intact tail (Fig. 3) and adult with regenerated tail (Fig. 4) from Valle Talloria, Cuneo. Photos: D. Raimondi (Figs. 1, 2) and R. Ghiglia (Figs. 3, 4). 
Ghezzi, 2019). Concerning Piedmont, the analysis of mean annual temperature anomalies relative to 1958-2015, with reference to 1971-2000, shows a long line of positive values from 1986 onwards and the total estimated rise is about $1{ }^{\circ} \mathrm{C}$ (Arpa Piemonte). The mean thermal anomalies of the last four years from the same reference value are positive too: $+1.3{ }^{\circ} \mathrm{C}(2016) ;+1.5{ }^{\circ} \mathrm{C}(2017) ;+1.6{ }^{\circ} \mathrm{C}$ (2018); $+1.5^{\circ} \mathrm{C}$ (2019). (Arpa Piemonte, Il Clima in Piemonte, 2016; 2017; 2018; 2019). Always with reference to 1971-2000, positive tendencies can be observed even in the trends of maximum and minimum daily temperatures relative to $1958-2015$, with rises of $+2{ }^{\circ} \mathrm{C}$ and $+1.5^{\circ} \mathrm{C}$ respectively (Arpa Piemonte). For the following years, these are the TMAX/TMIN pairs of values: $+1.8{ }^{\circ} \mathrm{C} /+0.8{ }^{\circ} \mathrm{C}$ (2016); $+2.3{ }^{\circ} \mathrm{C} /+0.8^{\circ} \mathrm{C}(2017) ;+1.9{ }^{\circ} \mathrm{C} /+1.4{ }^{\circ} \mathrm{C}$ (2018); $+1.8^{\circ} \mathrm{C} /+1.2^{\circ} \mathrm{C}$ (2019) (Arpa Piemonte, Il Clima in Piemonte, 2016; 2017; 2018; 2019).

Moreover, urban contexts can have much higher temperatures than rural ones: for example, the temperature differential of mean annual temperatures relative to 2002-2016 between the urban and the rural areas of Turin is $+1.7^{\circ} \mathrm{C}$ (Istat, 2018). This could positively affect especially the population observed in the city. In any case, the two populations have been observed on the walls of anthropic structures and even within them: a context where to find suitable parameters, also to compensate for any climatic unsuitability of the territory in which they settled.

In conclusion, in line with current climate changes, even Piedmont is subject to a rise of temperatures that could have played a role in the acclimatization of the Turkish Gecko in this region after accidental human transports. Further investigation is needed to establish the actual expansion of this species in Piedmont, also looking for the possible presence of individuals settled far from anthropic structures.

\section{ACKNOWLEDGEMENTS}

We would like to thank Giacomo Bruni (Sesto Fiorentino, Italy) for a preliminary review; Roberto Sindaco (Torino, Italy) and Elisa Serra (Cagliari, Italy) for their advices. No animals were either handled nor harmed during the making of this research.

\section{REFERENCES}

Benà M., 2007. Hemidactylus turcicus (Linnaeus, 1758). In: Bonato L., Fracasso G., Pollo R., Richard J. \& Semenzato M. (Eds.), Atlante degli Anfibi e dei Rettili del Veneto. Associazione Faunisti Veneti, Nuovadimensione, Portogruaro: pp. 130-132.

Bonardi A. \& Sindaco R., 2004. Hemidactylus turcicus (Linaeus, 1758). In: Bernini F., Bonini L., Ferri V., Gentilli A., Razzetti E. \& Scali S., 2004. Atlante degli Anfibi e dei Rettili della Lombardia. Monografie di Pianura n.5. Provincia di Cremona, Cremona, 255 pp.

Di Nicola M.R., Cavigioli L., Luiselli L. \& Andreone F., 2019. Anfibi \& Rettili d'Italia. Edizioni Belvedere, Latina, "le scienze" (31), 568 pp.

Istat, 2018. Temperatura e precipitazione nelle principali città. Anni 2002-2016. Report Statistiche. Available at: https://www.istat.it/it/archivio/temperature. Accessed on 6th April 2020.

IUCN, 2019. The IUCN Red List of Threatened Species. Version 2019-3. Available at: http://www.iucnredlist.org. Accessed on 6th April 2020.

Nardelli A., Iversen D. \& Tabarelli de Fatis K., 2016. Podarcis siculus and Hemidactylus turcicus, new herpetological records from Trentino-Alto Adige region (Italy). XI National Congress of the Societas Herpetologica Italica, Trento, Italy.

Novarini N., 2017. Hemidactylus turcicus (Linnaeus, 1758): third gecko species in the surroundings of Venice (Veneto, Italy). Biodiversità della Laguna di Venezia e della costa nord adriatica veneta. Biodiversity of the Lagoon of Venice and of the Venetian northern Adriatic coast. Bollettino del Museo di Storia Naturale di Venezia, 67: 158-161.

Pegorini M. \& Ghezzi D., 2019. Gechi a Cremona: nuove osservazioni. PIANURA - Scienze dell'Ambiente Padano, 38: 57-71.

Rondinini C., Battistoni A., Peronace V. \& Teofili C., (compilatori), 2013. Lista Rossa IUCN dei Vertebrati Italiani. Comitato Italiano IUCN e Ministero dell'Ambiente e della Tutela del Territorio e del Mare, Roma.

Sacchi R. \& Delaugerre M.D., 2011. Hemidactylus turcicus (Linnaeus, 1758). In: Corti C., Capula M., Luiselli L., Sindaco R. \& Razzetti E., Fauna d'Italia, vol. XLV, Reptilia. Calderini, Bologna, XII + 869 pp.

Speybroeck J., Beukema W., Bok B. \& Van Der Voort J., 2016. Field Guide to the Amphibians \& Reptiles of Britain and Europe. Bloomsbury Publishing Plc, 432 pp.

Venchi A., 2006. Hemidactylus turcicus (Linnaeus, 1758). In: Sindaco R., Doria G., Razzetti E. \& Bernini F. (Eds), Atlante degli Anfibi e dei Rettili d'I- 
talia / Atlas of Italian Amphibians and Reptiles. Societas Herpetologica Italica, Edizioni Polistampa, Firenze, 792 pp.

\section{SITOGRAPHY}

Arpa Piemonte. Available at: https://www. arpa.piemonte.it/ rischinaturali /tematismi/clima/confronti-storici/analisi- lungo. html. Accessed on 6th
April 2020.

Arpa Piemonte, Il Clima in Piemonte, 2016; 2017; 2018;

2019. Available at: https://www.arpa.piemonte. it/ rischinaturali/tematismi/clima/rapporti- di-analisi/annuale.html. Accessed on 6th April 2020.

iNaturalist. Available at: https://www.inaturalist.org. Accessed on 6th April 2020

Ornitho. Available at: http://www.ornitho.it. Accessed on 6th April 2020. 